\title{
Evaluation of the genotoxic activity of ethanol extract and secondary metabolites isolated from Aiouea trinervis Meisn. (Lauraceae)
}

\author{
Z.R. Guterres ${ }^{1}$, F.R. Garcez ${ }^{2}$, W.S. Garcez ${ }^{2}$, L.M.G.E. Silva ${ }^{2}$, A.F.G. Silva ${ }^{1}$, \\ C.U.N.B.D. Duarte ${ }^{1}$ and V.F. Batista-Silva ${ }^{1}$ \\ ${ }^{1}$ Grupo de Estudo de Ciências Ambientais e Educação (GEAMBE), \\ Universidade Estadual do Mato Grosso do Sul, Mundo Novo, MS, Brasil \\ ${ }^{2}$ CCET - Química, Universidade Federal de Mato Grosso do Sul, \\ Campo Grande, MS, Brasil
}

Corresponding author: Z.R. Guterres

E-mail: zairaguterres@yahoo.com.br

Genet. Mol. Res. 13 (1): 972-979 (2014)

Received December 17, 2012

Accepted July 6, 2013

Published February 19, 2014

DOI http://dx.doi.org/10.4238/2014.February.19.8

\begin{abstract}
Aiouea trinervis Meisn. is a shrub that grows in the "Cerrado" (a savanna ecosystem) of Brazil. In this study, fractionation of ethanol extracts (EEs) from the leaves of $A$. trinervis led to the isolation of butanolides, namely isoobtusilactone A and obtusilactone A, as well as lignans, namely sesamin, methylpiperitol, and polyprenol-12. Their structures were determined by spectroscopic analyses. The genotoxic properties were evaluated for mutagenic and recombinogenic effects using the wing spot test (somatic mutation and recombination test, SMART) on Drosophila melanogaster. The standard and high bioactivation crosses were used. The latter cross is characterized by high sensitivity to promutagens and procarcinogens. EEs were evaluated at concentrations of $0.625,1.25$, and $2.5 \mathrm{mg} / \mathrm{mL}$. Butanolides (isoobtusilactone A and obtusilactone A) were evaluated at concentrations of $0.1,0.2$, and 0.3 $\mathrm{mg} / \mathrm{mL}$. The results observed in both crosses were similar and indicated that EEs from the leaves of $A$. trinervis did not show genotoxicity at the
\end{abstract}


doses that were used. However, the individuals resulting from standard and high bioactivation crosses that were treated with isoobtusilactone $\mathrm{A}$ and obtusilactone A showed statistically significant increases in mutant spots compared to those that were obtained in the negative control. Similar results were obtained between standard and high bioactivation crosses, indicating that butanolides had a genotoxic activity.

Key words: Somatic mutation and recombination test; Butanolides; Aiouea trinervis; Drosophila melanogaster

\section{INTRODUCTION}

Aiouea trinervis Meisn., 1864 (Laurales, Lauraceae) is a shrub that grows in the "Cerrado" (a savanna ecosystem) of Mato Grosso do Sul, Brazil, and is considered to be an endangered Brazilian species (Garcez et al., 2005). As previously demonstrated, the fractionation of ethanol extracts (EEs) from the roots, underground trunk, and the leaves of $A$. trinervis led to the isolation of 4 butanolides ( $\gamma$-lactones), namely (-)-epilitsenolides C-2 and C-1, isoobtusilactone A, and obtusilactone $\mathrm{A}$, and the lignans $(+)$-sesamin, $(+)$-methylpiperitol, and polyprenol-12 (Garcez et al., 2005).

Lauraceae is an economically important family, with 52 genera and approximately 2500-2750 species. It consists mostly of trees or tree-like shrubs that are rich in biologically active secondary metabolites, such as neolignans, $\gamma$-lactones, alkaloids, flavonoids, and terpenes. These secondary metabolites have shown different biological properties: cytotoxic (Tsai et al., 2000; Chang et al., 2008) and genotoxic (Garcez et al., 2005).

Natural products are currently valuable tools to understand the biosynthesis and development of new medicines. Between 1981 and 2006, the Food and Drug Administration (FDA) approved 1184 new chemical entities, of which, 70\% were derived from, related to, or directly obtained from natural products, especially of vegetal origin. Of the 81 new chemical entities that were approved for the treatment of cancer, only $22 \%$ are of synthetic origin - the remainders have at least a link to natural-origin products (Newman and Cragg, 2007).

The objective of this study was to evaluate the possible genotoxic effects of EEs and the secondary metabolites (butanolides) isoobtusilactone A and obtusilactone A that were isolated from A. trinervis, in somatic cells of Drosophila melanogaster, using the somatic mutation and recombination test (SMART).

\section{MATERIAL AND METHODS}

\section{Chemicals}

Doxorubicin (DXR) (Doxolen ${ }^{\circledR}$, Eurofarma Laboratórios Ltda., São Paulo, SP, Brazil (CAS 23214-92-8) was obtained from the Clinical Hospital of the Federal University of Uberlândia, MG, Brazil. The EEs from leaves and butanolides (isoobtusilactone A and obtusilactone A) that were investigated in this study were produced and supplied by the Chemistry Department at the Federal University of Mato Grosso do Sul (UFMS), Campo Grande, MS, Brazil (see Garcez et al., 2005). 
The EEs and butanolides were always freshly prepared immediately before use and dissolved in 1\% Tween 80 (Labsynth Produtos para Laboratórios Ltda., Diadema, SP, Brazil), 3\% ethanol (Proquímios, Rio de Janeiro, RJ, Brazil), and distilled water.

\section{SMART}

The markers multiple wing hairs $(m w h, 3-0.3)$ and flare-3 $\left(f r^{3}, 3-38.8\right)$ are at the tip and roughly in the middle of the left arm of chromosome 3, respectively. Two crosses were carried out to produce the experimental larval progeny. The standard (ST) cross was performed as $\mathrm{fr}^{3} / \operatorname{In}(3 L R) T M 3$, ri $p^{p}$ sep l(3)89Aa bx ${ }^{34 e}$ e $B d^{S}$ females crossed with $m w h / m w h$ males. The high bioactivation (HB) cross was performed as ORR/ORR; $f r^{3} / \operatorname{In}(3 L R) T M 3, r i$ $p^{p}$ sep l(3)89Aa bx $x^{34 e}$ e $B d^{S}$ females crossed with $m w h / m w h$ males (Graf et al., 1984; Graf and van Schaik, 1992).

From both crosses, eggs were collected for $8 \mathrm{~h}$ in culture bottles with an agar-agar base $(4 \%, w / v)$ topped with a thick layer of live baker's yeast supplemented with sucrose. The larvae were washed out of the bottles $72 \pm 4 \mathrm{~h}$ later with tap water and collected in a stainless steel strainer.

In a pilot experiment, the lethal dose of EEs for $50 \%$ of individuals $\left(\mathrm{LD}_{50}\right)$ was determined. The toxicities for adult flies were $20 \mathrm{mg} / \mathrm{mL}$ EEs and $2 \mathrm{mg} / \mathrm{mL}$ butanolides.

For chronic feeding, a series of vials were prepared with $1.5 \mathrm{~g}$ mashed potato flakes (Yoki ${ }^{\circledR}$ Alimentos S.A., Brazil) and $5 \mathrm{~mL}$ of a solution containing a final concentration of $0.625,1.25$, and $2.5 \mathrm{mg} / \mathrm{mL}$ EEs from leaves of $A$. trinervis. Butanolides were evaluated at concentrations of $0.1,0.2$, and $0.3 \mathrm{mg} / \mathrm{mL}$. Negative ( $1 \%$ Tween 80 and $3 \%$ ethanol in distilled water) and positive (DXR, $0.125 \mathrm{mg} / \mathrm{mL}$ ) controls were included in both experiments. Each treatment was conducted in duplicate. Each cross produced 2 types of progeny, marker-heterozygous (MH) $\left(m w h+/+f l r^{3}\right)$ and balancer-heterozygous (BH) $\left(m w h+/+T M 3, B d^{S}\right)$ flies. The dominant $B d^{S}$ marker allows the wings of these 2 genotypes to be distinguished. The hatched flies were stored in $70 \%$ ethanol (v/v). The wings were removed and mounted on slides with Faure's solution and analyzed under a compound microscope at 400X magnification (Graf et al., 1984). The frequency and size of single and twin spots were recorded.

\section{Evaluation of the data and statistical analysis}

To evaluate the induced effects, the frequencies of spots per wing were analyzed with a computer program based on the 2 alternative hypotheses method that was proposed by Frei and Würgler (1988). This method tests 2 alternative hypotheses: i) the mutation frequency in the treated group is no higher than the mutation frequency in the control group; ii) the frequency in the treated group is no less than $m$ times as high as the observed spontaneous mutation frequency in the control. For the statistical calculations, the Kastenbaum-Bowman test (Kastenbaum and Bowman, 1970) was used with significance levels $\alpha=\beta=0.05$. Based on the clone induction frequencies per $10^{5}$ cells, the recombinogenic activity was calculated as the following: mutation frequencies $(F \mathrm{M})=$ frequency of $\mathrm{BH}$ clone flies/frequency of $\mathrm{MH}$ clone flies; recombination frequencies $(F \mathrm{R})=1-F \mathrm{M}$. Frequencies of total spots $(F \mathrm{~T})=$ total spots in $\mathrm{MH}$ flies (considering $m w h$ and $f r^{3}$ spots)/No. of flies; mutation $=F \mathrm{~T} \times F \mathrm{M}$; recombination $=$ FT x FR (Santos et al., 1999; Sinigaglia et al., 2006). 


\section{RESULTS AND DISCUSSION}

To evaluate the genotoxicity of the EEs from the leaves of $A$. trinervis and the butanolides (isoobtusilactone A and obtusilactone A) isolated from this extract, each treatment was performed in duplicate. The doses that were used were determined through a pilot experiment. The data that were obtained in the MH $\left(m w h / f r^{3}\right)$ progeny were pooled after verifying that the 2 independent experiments agreed, and these are summarized in Table 1. The frequencies of observed spots were classified as small single, large single, twin, and total spots.

\begin{tabular}{|c|c|c|c|c|c|c|}
\hline \multirow[t]{2}{*}{ Genotypes and treatments } & \multirow[t]{2}{*}{ No. of flies } & \multicolumn{4}{|c|}{ Spots per fly (number of spots) statistical diagnosis ${ }^{\mathrm{a}}$} & \multirow[t]{2}{*}{ Spots with $m w h$ clone } \\
\hline & & $\begin{array}{c}\text { Small single } \\
\text { spots }(1-2 \text { cells })^{\mathrm{b}} \\
\mathrm{m}=2\end{array}$ & $\begin{array}{c}\text { Large single } \\
\text { spots }(>2 \text { cells })^{\mathrm{b}} \\
\mathrm{m}=5\end{array}$ & $\begin{array}{c}\text { Twin spots } \\
\mathrm{m}=5\end{array}$ & $\begin{array}{c}\text { Total spots } \\
\mathrm{m}=2\end{array}$ & \\
\hline \multicolumn{7}{|l|}{ ST cross } \\
\hline \multicolumn{7}{|l|}{$\mathrm{EE}(\mathrm{mg} / \mathrm{mL})$} \\
\hline 0 & 60 & $0.17(10)$ & $0.05(03)$ & $0.02(01)$ & $0.23(14)$ & 14 \\
\hline 0.625 & 60 & $0.22(13) \mathrm{i}$ & $0.02(01) \mathrm{i}$ & $0.02(01) \mathrm{i}$ & $0.25(15) \mathrm{i}$ & 15 \\
\hline 1.25 & 60 & $0.23(14) \mathrm{i}$ & $0.02(01) \mathrm{i}$ & $0.02(01) \mathrm{i}$ & $0.27(16) \mathrm{i}$ & 16 \\
\hline 2.5 & 60 & $0.27(16) \mathrm{i}$ & $0.02(01) \mathrm{i}$ & $0.02(01) \mathrm{i}$ & $0.30(18) \mathrm{i}$ & 18 \\
\hline DXR & 60 & $3.70(222)+$ & $5.35(312)+$ & $7.23(434)+$ & $16.28(977)+$ & $947 *$ \\
\hline \multicolumn{7}{|l|}{$\mathrm{HB}$ cross } \\
\hline \multicolumn{7}{|l|}{$\mathrm{EE}(\mathrm{mg} / \mathrm{mL})$} \\
\hline 0 & 60 & $0.28(17)$ & $0.02(01)$ & $0.02(01)$ & $0.32(19)$ & 19 \\
\hline 0.625 & 60 & 0.28 (17)- & $0.03(02) \mathrm{i}$ & $0.02(01) \mathrm{i}$ & $0.33(20)-$ & 20 \\
\hline 1.25 & 60 & $0.35(21) \mathrm{i}$ & $0.05(03) \mathrm{i}$ & $0.00(00) \mathrm{i}$ & $0.40(24) \mathrm{i}$ & 24 \\
\hline 2.5 & 60 & $0.25(15)-$ & $0.07(04) \mathrm{i}$ & $0.02(01) \mathrm{i}$ & $0.33(20)-$ & 20 \\
\hline DXR & 60 & $2.20(132)+$ & $7.18(431)+$ & $10.27(616)+$ & 19.65 (1179) & $1150^{*}$ \\
\hline
\end{tabular}

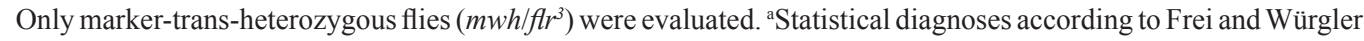
(1988). $U$-test, two-sided; probability levels: $(-)=$ negative; $(+)=$ positive; $\mathrm{i}=$ inconclusive; $\mathrm{m}=$ multiplication factor; $* \mathrm{P} \leq 0.05 v s$ untreated control. ${ }^{\mathrm{b}}$ Including rare $f l r^{3}$ single spots. ${ }^{\mathrm{c}}$ Considering $m w h$ clones from $m w h$ single and twin spots.

The data obtained from the treatment with the EEs from the leaves of $A$. trinervis were compared to the negative control. EEs from the leaves at concentrations of 0.625 , 1.25 , and $2.50 \mathrm{mg} / \mathrm{mL}$ did not produce statistically significant increases in the spontaneous mutation rate that was observed in the negative control, and the observed results were inconclusive or negative for all spot categories. Similar effects were observed in the $\mathrm{MH}$ progeny of both the ST and HB crosses.

In this study, no genotoxic activity of this plant's leaf extract was detected at the evaluated concentrations, which was assessed by means of SMART. Cytotoxic effects at $2.0 \times 10^{4} \mu \mathrm{g} / \mathrm{mL}$ were observed for organic extracts from different parts of A. trinervis in Chinese hamster ovary (CHO) cells (Garcez et al., 2005). A possible hypothesis for the negative results in the SMART assay is that the concentration of the extracts used is insufficient or that different effect levels exist for different genetic endpoints that are measured in SMART.

However, when the genotoxic activity of butanolides (isoobtusilactone A and obtsusilactone A) was evaluated (Table 2), increases were observed in single small spots, 
which were statistically significant when compared to the negative control. The analysis of the BH descendants $(\mathrm{mwh} / \mathrm{TM} 3)$ showed that the frequencies of mutant spots that were induced by all concentrations of isoobtusilactone A and obtusilactone A were statistically significant when compared with the negative control. In order to determine the frequency of mutation and recombination, we compared the results that were obtained in $\mathrm{BH}$ with the MH descendants $\left(\mathrm{mwh} / \mathrm{fl} \mathrm{r}^{3}\right)$. The results indicated that $30 \%$ less recombination occurred with butanolides (Table 3). This indicates that isoobtusilactone A and obtusilactone A are capable of interfering with DNA, leading to mutations or mitotic crossover, thus showing genotoxic activity. Similar results were observed in the HB cross (Table 3).

\begin{tabular}{|c|c|c|c|c|c|c|c|c|c|}
\hline \multirow{3}{*}{$\begin{array}{l}\text { Genotypes and } \\
\text { treatments }\end{array}$} & \multirow{3}{*}{$\begin{array}{l}\text { No. of } \\
\text { flies }\end{array}$} & \multicolumn{4}{|c|}{ Spots per fly (number of spots) statistical diagnosis ${ }^{\mathrm{a}}$} & \multirow{3}{*}{$\begin{array}{l}\text { Spots with } \\
m w h \text { clone }^{c}\end{array}$} & \multirow{2}{*}{\multicolumn{2}{|c|}{$\begin{array}{l}\text { Frequency of clone } \\
\text { formation } / 10^{5} \text { cells } \\
\text { per cell division }\end{array}$}} & \multirow{3}{*}{$\begin{array}{c}\text { Frequency of } \\
\text { recombination (\%) }\end{array}$} \\
\hline & & \multirow{2}{*}{$\begin{array}{c}\text { Small single } \\
\text { spots }(1-2 \text { cells })^{b} \\
m=2\end{array}$} & \multirow{2}{*}{$\begin{array}{c}\text { Large single } \\
\text { spots }(>2 \text { cells })^{\mathrm{b}} \\
\mathrm{m}=5\end{array}$} & \multirow{2}{*}{$\begin{array}{c}\text { Twin spots } \\
\mathrm{m}=5\end{array}$} & \multirow{2}{*}{$\begin{array}{l}\text { Total spots } \\
\mathrm{m}=2\end{array}$} & & & & \\
\hline & & & & & & & Observed & $\begin{array}{c}\text { Control } \\
\text { corrected }\end{array}$ & \\
\hline \multicolumn{10}{|l|}{$\begin{array}{l}\mathrm{OBT}(\mathrm{mg} / \mathrm{mL}) \\
m w h / f r^{3}\end{array}$} \\
\hline 0 & 40 & $0.48(19)$ & $0.10(04)$ & $0.03(01)$ & $0.60(24)$ & 24 & 1.23 & & \\
\hline 0.1 & 40 & $1.03(41)^{+}$ & $0.08(03) \mathrm{i}$ & $0.05(02) \mathrm{i}$ & $1.15(46)+$ & $46^{*}$ & 2.36 & 1.13 & 26 \\
\hline 0.2 & 40 & $1.13(45)^{+}$ & $0.13(05) \mathrm{i}$ & $0.05(02) \mathrm{i}$ & $1.30(54)+$ & $54 *$ & 2.78 & 1.53 & 28 \\
\hline 0.3 & 40 & $1.50(60)^{+}$ & $0.15(06) \mathrm{i}$ & $0.03(01) \mathrm{i}$ & $1.68(67)+$ & $67^{*}$ & 3.43 & 2.20 & 27 \\
\hline \multicolumn{10}{|l|}{$m w h / T M 3$} \\
\hline 0 & 40 & $0.35(14)$ & $0.02(01)$ & & $0.37(15)$ & 15 & 0.77 & & \\
\hline 0.1 & 40 & $0.80(32)+$ & $0.05(02) \mathrm{i}$ & & $0.85(34)+$ & $34 *$ & 1.74 & 0.97 & \\
\hline 0.2 & 40 & $0.95(38)+$ & $0.02(01) \mathrm{i}$ & & $0.97(39)+$ & $39^{*}$ & 2.00 & 1.23 & \\
\hline 0.3 & 40 & $1.12(47)^{+}$ & $0.05(02) \mathrm{i}$ & & $1.17(49)+$ & $49^{*}$ & 2.51 & 1.74 & \\
\hline \multicolumn{10}{|l|}{$\begin{array}{l}\mathrm{ISO}(\mathrm{mg} / \mathrm{mL}) \\
m w h / f t r^{3}\end{array}$} \\
\hline 0.1 & 40 & $0.73(29) \mathrm{i}$ & $0.18(07) \mathrm{i}$ & $0.05(02) \mathrm{i}$ & $0.95(38)+$ & $38^{*}$ & 1.95 & 1.18 & 24 \\
\hline 0.2 & 40 & $0.80(32)+$ & $0.23(09) \mathrm{i}$ & $0.05(02) \mathrm{i}$ & $1.08(43)+$ & $43^{*}$ & 2.20 & 1.43 & 21 \\
\hline 0.3 & 40 & $0.78(31) \mathrm{i}$ & $0.20(08) \mathrm{i}$ & $0.08(03) \mathrm{i}$ & $1.05(42)+$ & $42^{*}$ & 2.15 & 1.38 & 19 \\
\hline \multicolumn{10}{|l|}{$m w h / T M 3$} \\
\hline 0.1 & 40 & $0.67(27)^{+}$ & $0.05(02) \mathrm{i}$ & & $0.72(29)+$ & $29^{*}$ & 1.48 & 0.71 & \\
\hline 0.2 & 40 & $0.73(29)^{+}$ & $0.13(05)^{+}$ & & $0.85(34)+$ & $34^{*}$ & 1.74 & 0.97 & \\
\hline 0.3 & 40 & $0.75(30)^{+}$ & $0.10(04) \mathrm{i}$ & & $0.85(34)+$ & $34 *$ & 1.74 & 0.97 & \\
\hline
\end{tabular}

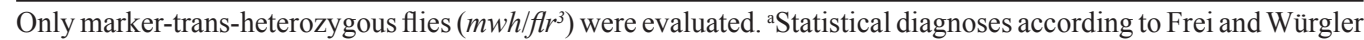
(1988). $U$-test, two-sided; probability levels: $(-)=$ negative; $(+)=$ positive; $\mathrm{i}=$ inconclusive; $\mathrm{m}=$ multiplication factor; ${ }^{*} \mathrm{P} \leq 0.05$ vs untreated control. ${ }^{b}$ Including rare $f l r^{3}$ single spots. ${ }^{\circ}$ Considering $m w h$ clones from $m w h$ single and twin spots. ${ }^{\mathrm{d}}$ Frequency of clone formation: clones/flies/48,000 cells.

Obtusilactone and isoobtusilactone from Cinnamomum camphora showed mild cytotoxic activity when tested in vitro against a lymphoblastic leukemia cell line (L1210) (Mukherjee et al., 1994).

Observations by Chen et al. (2008) indicate that isoobtusilactone A induces DNA fragmentation and apoptosis, inhibiting the growth of tumor cells. This compound exhibited cytotoxic and genotoxic effects on a variety of cell types, including human laryngeal carcinoma Hep-2, CHO-K1, rat hepatoma cell HTC (Garcez et al., 2005), and mouse lymphoid leukemia P-388 (Tsai et al., 2002). Liu et al. (2008) suggested that isoobtusilactone A-induced apoptotic cell death was mediated via both caspase-dependent and -independent pathways. 
Evaluation of the genotoxic activity of Aiouea trinervis

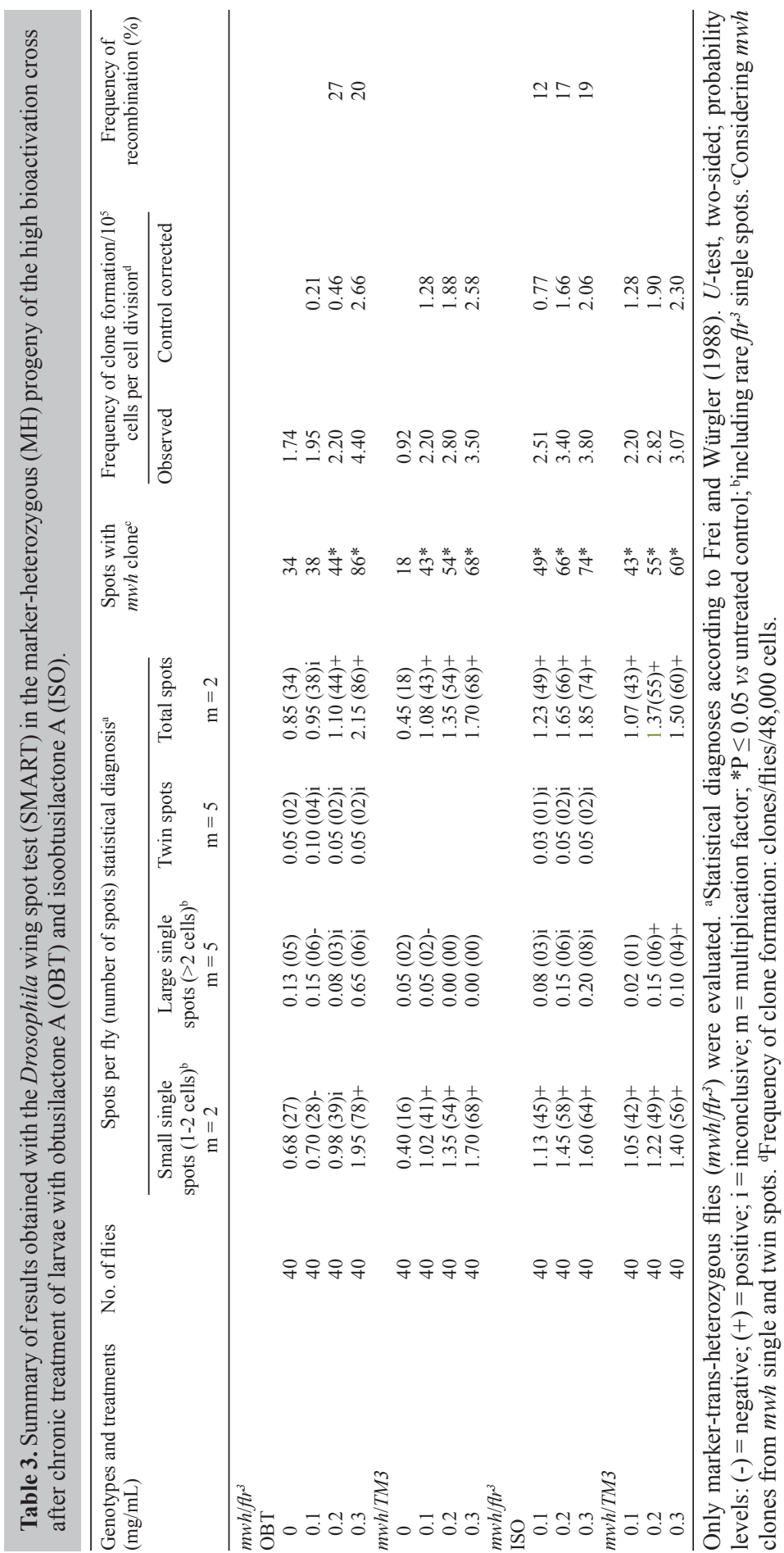


Isoobtusilactone A displayed cytotoxic activity in Hep-2 human cancer cells and DNA damage in CHO-K1 and HTC mammalian cells that were assayed by single-cell gel electrophoresis (comet assay) (Garcez et al., 2005). When isolated from the stem wood of Formosan Lindera communis, it showed cytotoxic effects against P-388 cancer cells (Tsai et al., 2002). When isolated from the leaves of $C$. kotoense, it proved to be an agent that was capable of inducing anticancer effects in 2 human breast cancer cell lines, MCF-7 and MDA-MB-231 (Kuo et al., 2007) and human non-small cell lung cancer A549 cells (Chen et al., 2008). Additionally, the apoptotic cell death of Hep G2 cells was mediated via both caspase-dependent and -independent pathways (Liu et al., 2008).

Few reports exist about the biological activity of obtusilactone A, but this chemical entity belongs to the butanolide class of chemicals, which includes $\gamma$-lactones. Several biological activities are reported for $\gamma$-lactones, including cytotoxic and antiproliferative activities, showing an antitumoral potential (Catene et al., 2006; Albrecht et al., 2010).

\section{CONCLUSIONS}

Under the experimental conditions described herein, the EEs that were obtained from leaves of A. trinervis did not show genotoxic activity. However, the butanolides (isoobtusilactone $\mathrm{A}$ and obtusilactone A) that were isolated from this extract did show genotoxic activity.

Chemical entities that are isolated from plants and show biological activities, such as cytotoxic, apoptosis-inducing, antiproliferative, and antitumoral activities, are promising candidates for the production of new drugs. Further studies applying different test systems, experimental protocols, and other end-points are required to better characterize and understand the properties of isoobtusilactone A and obtusilactone A and to contribute to new discoveries with therapeutic ends.

\section{ACKNOWLEDGMENTS}

The authors thank the Federal University of Uberlândia (UFU), State University of Mato Grosso do Sul (UEMS), Dr. Arnildo Pott, and Brazilian agencies CAPES, FUNDECT$\mathrm{MS}, \mathrm{CNPq}$, and FAPEMIG.

\section{REFERENCES}

Albrecht L, Wojciechowshi J, Albrecht A, Wojciech MW, et al. (2010). Synthesis and cytotoxic evaluation of $\beta$-alkyl or $\beta$-aryl- $\delta$-methyl- $\alpha$-methylene- $\delta$-lactones. Comparison with the corresponding $\gamma$-lactones. Eur. J. Med. Chem. 45: 710-718.

Catene F, Zilic J, Zacchigna M and Bonivento P (2006). Synthesis and biological properties of new $\alpha$-methylene- $\gamma$ butyrolactones and $\alpha, \beta$-unsaturated $\delta$-lactones. Eur. J. Med. Chem. 41: 192-200.

Chang SY, Cheng MJ, Kuo YH, Lee SJ, et al. (2008). Secondary metabolites from the stem bark of Litsea akoensis and their cytotoxic activity. Helv. Chim. Acta 91: 1156-1165.

Chen CY, Chen CH, Lo YC, Wu BN, et al. (2008). Anticancer activity of isoobtusilactone A from Cinnamomum kotoense: involvement of apoptosis, cell-cycle dysregulation, mitochondria regulation, and reactive oxygen species. J. Nat. Prod. 71: 933-940.

Frei H and Würgler FE (1988). Statistical methods to decide whether mutagenicity test data from Drosophila assays indicate a positive, negative, or inconclusive result. Mutat. Res. 203: 297-308.

Garcez FR, Garcez WS, Martins M, Matos MF, et al. (2005). Cytotoxic and genotoxic butanolides and lignans from Aiouea trinervis. Planta Med. 71: 923-927. 
Graf U and van Schaik N (1992). Improved high bioactivation cross for the wing somatic mutation and recombination test in Drosophila melanogaster. Mutat. Res. 271: 59-67.

Graf U, Würgler FE, Katz AJ, Frei H, et al. (1984). Somatic mutation and recombination test in Drosophila melanogaster. Environ. Mutagen. 6: 153-188.

Kastenbaum MA and Bowman KO (1970). Tables for determining the statistical significance of mutation frequencies. Mutat. Res. 9: 527-549.

Kuo PL, Chen CY and Hsu YL (2007). Isoobtusilactone A induces cell cycle arrest and apoptosis through reactive oxygen species/apoptosis signal-regulating kinase 1 signaling pathway in human breast cancer cells. Cancer Res. 67: 74067420.

Liu TZ, Cheng JT, Yiin SJ, Chen CY, et al. (2008). Isoobtusilactone A induces both caspase-dependent and -independent apoptosis in Hep G2 cells. Food Chem. Toxicol. 46: 321-327.

Mukherjee RK, Fujimoto Y and Kokinuma K (1994). 1-( $\omega$-hydroxyfattyacyl) glycerols and two flavanols from Cinnamomum camphora. Phytochemistry 37: 1641-1643.

Newman DJ and Cragg GM (2007). Natural products as sources of new drugs over the last 25 years. J Nat. Prod. 70: 461-477.

Santos JH, Graf U, Reguly ML and Rodrigues de Andrade HH (1999). The synergistic effects of vanillin on recombination predominate over its antimutagenic action in relation to MMC-induced lesions in somatic cells of Drosophila melanogaster. Mutat. Res. 444: 355-365.

Sinigaglia M, Lehmann M, Baumgardt P, do Amaral VS, et al. (2006). Vanillin as a modulator agent in SMART test: inhibition in the steps that precede N-methyl-N-nitrosourea-, N-ethyl-N-nitrosourea-, ethylmethanesulphonate- and bleomycin-genotoxicity. Mutat. Res. 607: 225-230.

Tsai IL, Chen JH, Duh CY and Chen IS (2000). Cytotoxic neolignans from the stem wood of Machilus obovatifolia. Planta Med. 66: 403-407.

Tsai IL, Hung CH, Duh CY and Chen IS (2002). Cytotoxic butanolides and secobutanolides from the stem wood of Formosan Lindera communis. Planta Med. 68: 142-145. 